\title{
Så var det min tur
}

\author{
Sykehuspresten ble selv kreftpasient.
}

Den iranskfødte legen satte noen svarte øyne i meg og sa: «Jaj vil vare arlig med deg - dette er alvorr!»

Jeg takket for hans oppriktighet og mente det. Ingen har ennå dødd av klare beskjeder, men mange har fått ekstra problemer av tåketale.

Og så gikk det unna - strålebehandling og cellegift, heldags operasjon - og plutselig var jeg stomipasient på livstid.

For det var min tur - første gang på den andre siden av bordet. Jeg, som hadde vært sykehusprest, forrettet begravelse for hundrevis av mennesker, vært styreleder for somatiske og psykiatriske sykehus - alltid den friske, den som skulle ta hånd om andre.

«Hvorfor skulle dette hende meg - og så akkurat nå!» Det utsagnet har jeg hørt utallige ganger. Slik tenkte ikke jeg - tvert imot. Jeg sa: «Så ble det altså min tur det er jo ingen bombe! Titusener har hatt denne opplevelsen før meg.»

Så begynte spaserturen gjennom systemet - og det fungerte faktisk. Minimalt med ventetid, vakker kombinasjon av faglighet og menneskelighet. Sannelig dukket det ikke opp en engel også. En grønnkledd - helt uten vinger og fjær. Hun sto der plutselig like før jeg ble trillet inn til opera- sjonen. Hun smilte til meg, strøk meg over kinnet og sa: «Vær trygg, der inne er de beste - de kommer til å gjøre alt de kan for at dette skal gå bra!» Og det gjorde det.

Når jeg ser tilbake, er det tusen ting jeg har observert og gjerne kunne kommentere. Men her får jeg nøye meg med to.

Jeg fikk oppmerksomhet. Ikke bare den faglige - det er selvsagt. Men de så meg inn i øynene, de møtte meg som person, de ønsket meg lykke til.

Oppmerksomhet er en nær slektning av respekt. Mange vet at ordet «respekt» kommer av det latinske verbet «re-spektare», som betyr å se tilbake eller å se én gang til. Respekt handler altså både om å se og å bli sett. Oppmerksomhet. Det er min ærbødige påstand at oppmerksomhet styrker det mentale immunforsvaret og dermed bidrar til helbredelse. (Nei, jeg kan ikke vise til evidensbasert forskning.) Når noen ser meg og respekterer meg, får jeg lyst til å leve. Kjempe litt til.

Det andre stikkordet er team. Jeg skal jo ikke garantere at alt var rosenrødt bak kulissene (les: forhenget), men jeg så team i fint koordinert funksjon. Ikke slik at noen var hovedaktører og andre assistenter, det var mer som et sinnrikt urverk i en mekanisk klokke der tannhjulene griper i hverandre så det hele går rundt. Dersom det aller minste hjulet stanser, så stopper hele greia.

I ettertid har jeg tenkt mye på hvor lang tid det tar å bygge opp et slikt team - fordi det ikke dreier seg om marionetter, men om mennesker. Derfor er det mange små menneskelige detaljer som enten bidrar til eller hemmer et team.

Tilsvarende tar det skremmende kort tid å ødelegge det - hvis omorganisering fører til at teamet oppløses og blir til enkeltbrikker som puttes inn i huller andre steder. Slik det skjedde med «mitt» sykehus.

Jeg er også blitt en «brikke» nå. Jeg sendes hit og dit i systemet. Og PC-ene på de forskjellige stedene klarer ikke kommunisere med hverandre, hvilket fører til komiske misforståelser. Men det gjør for så vidt ikke så mye - for jeg er frisk og må tåle det.

Så i en viss forstand av uttrykket var det likevel ikke «min tur».

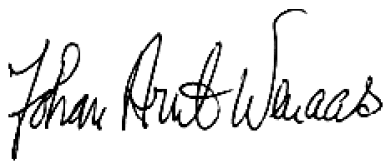

